\title{
VYUŽITÍ CHATBOTU゚ V KURZU INFORMAČNÍ GRAMOTNOSTI
}

RNDr. Michal Černý; mcerny@phil.muni.cz; (Katedra informačních studií a knihovnictví, Filozofická fakulta Masarykovy univerzity v Brně)

Článek na príkladech tříchatbotů ukazuje, jakým způsobem je možné tyto dialogové systémy využítvinformačním vzdělávání. Pracuje s nástrojem Snatchbot.me, který umožňuje jednoduchou tvorbu chatbotů i bez znalosti programování. Článek současně diskutuje proces vývoje, jeho praktickou implementaci a zdůrazňuje význam práce s konstruktivistickými metodami v jeho tvorbě. Chatbot představuje zajímavý prvek, který může rozšiřit portfolio vzdělávacích objektů, se kterými knihovna v oblasti informačního vzdělávání pracuje a zlepšit kvalitu informačního vzdělávání jako takového.

https://doi.org/10.52036/1335793X.2021.3-4.28-35

Rozvoj informační gramotnosti je (nejen) v českém prostředí dlouhodobou doménou knihoven, a to jak na úrovni základních, tak vysokých škol. V prípadě základních škol můžeme vidět silné zapojení obecních knihoven ${ }^{1}$, které prostřednictvím učících knihovníkü ${ }^{2}$ pracují s cílovou skupinou základních škol, v českém prostředí byly realizovány projekty (Co nebylo $\mathrm{v}$ učebnici) ${ }^{3}$, které tyto dvě instituce právě nad tématem informačního vzdělávání propojovaly.

Vedle toho můžeme vidět vícekolejnou péči o studenty vysokoškolské, at již formou aktivit vedoucích $\mathrm{k}$ seznámení se s knihovním fondem, službami knihoven, nebo i povinné a volitelné kurzy $v$ kurikulu jednotlivých oborů, které se zaměřují na specifické potřeby dané skupiny vysokoškolských studentů. Existuje zde také velké množství workshopů, ale i online vzdělávacích kurzů zaměřených na určité oblasti práce $s$ informacemi, nejčastěji spojené s tvorbou vlastního odborného textu. ${ }^{4}$

Mezi těmito dvěma poměrně dobře saturovanými skupinami se nachází středoškolští studenti, kteří se ocitají mimo klasické institucionální podporující rámce. Střední školy s knihovnami spolupracují spíše zřídka, případně se zaměřují na oborové problémy konkrétních předmětů. $V$ českém kurikulárním systému není informační gramotnost přímo zakotvena jako samostatný předmět nebo klíčová kompetence, ale z našeho výzkumu kurikula tři středních škol současně plyne, že jde o téma reflektované vzdělávacími institucemi, které si uvědomují, že by s ním měli aktivně pracovat. Náš předchozí výzkum ukázal, že školy i sami studenti téma aktivně reflektují a vnímají ho jako potřebné pro svoji vlastní edukaci. ${ }^{5}$

$\checkmark$ českém prostředí chybí širší tradice knihoven a informačních center, která známe například z USA, která se právě rozvoji informační gramotnosti silně věnují, a přesto studie jasně deklarují, že z hlediska informační gramotnosti je přechod mezi střední školou a univerzitou $v$ USA velice problematický. Lze hovořit o těsné souvislosti mezi informační gramotností a kompetencemi k učení, což nás vede $\mathrm{k}$ úvaze nad tím, zda mimořádně vysoká studijní neúspěšnost univerzitních studentů v ČR není s tímto fenoménem také spojená. Informační gramotnost má ale také vliv na pracovní úspěchy nebo zdravotní gramotnost a jednoznačně tak přispívá ke kvalitě života jako takového. Studie také dokládají, že dostupnost zdrojů a schopnost s nimi pracovat, je pro středoškolské studenty zásadní, z hlediska budování vlastní identity. ${ }^{8}$

$Z$ těchto poznatků jasně vyplývá požadavek na tvorbu vzdělávacích aktivit, které budou zaměřené na středoškolské studenty a umožní jim informační gramotnost adekvátním způsobem rozvíjet. Na tomto půdorysu vznikl projekt podpořený Technologickou agenturou České republiky s názvem Platforma pro transfer znalostí: informační gramotnost pro středoškoláky v otevřeném mash-up virtuálním učebním prostředí. Jeho cílem bylo vytvořit učební prostředí pro středoškolské studenty a jejich učitele, které budou moci použít pro rozvoj informační gramotnosti, at' již formou sebevzdělávání nebo přenesením témat do školního prostředí (celý kurz je dostupný z https://kisk.phil.muni. cz/onlife).

To je spojené jak s nutností promyslet obsah takového kuru, tak také s potřebou hledání edukačních forem. Jednou z nich jsou chatboti ${ }^{9}$, na které bychom se $v$ tomto článku rádi zaměřili. Domníváme se, že jejich tvorba není náročná a může představovat uživatelsky atraktivní formu vzdělávání, která odstraňuje některé problémy klasicky chápaných vzdělávacích materiálů. 
TVORBA CHATBOTA V APLIKACI Snatchbot.me Obecně lze říci, že chatbot je aplikace, která slouží pro komunikaci, obvykle $v$ textové podobě s uživatelem nějakou automatizovanou formou. $V$ současné době se díky rozvoji umělé inteligence objevují různé systémy, které dokáží vést konverzaci na téměř libovolné téma (obvykle v angličtině), ale centru naší pozornosti budou takové formy chatbotů u nichž Ize hovořit o algoritmizovaném postupu $\mathrm{v}$ dialogu. ${ }^{10}$
Tvorba takového chatbota, který pracuje s automatizovanými a algoritmizovanými odpověd'mi není obtížná, protože existuje velké množství nástrojů, které umožňují tvorbu na několik málo kliknutí. To, co náročné může být je vymyslet smysluplný a funkční dialog. Na základě poměrně obsáhlého zkoušení a rešerší jsme se rozhodli využít pro tvorbu aplikaci Snatchbot. me (https://snatchbot.me/), která je uživatelsky pravděpodobně jedena $z$ nejjednodušších a současně na-

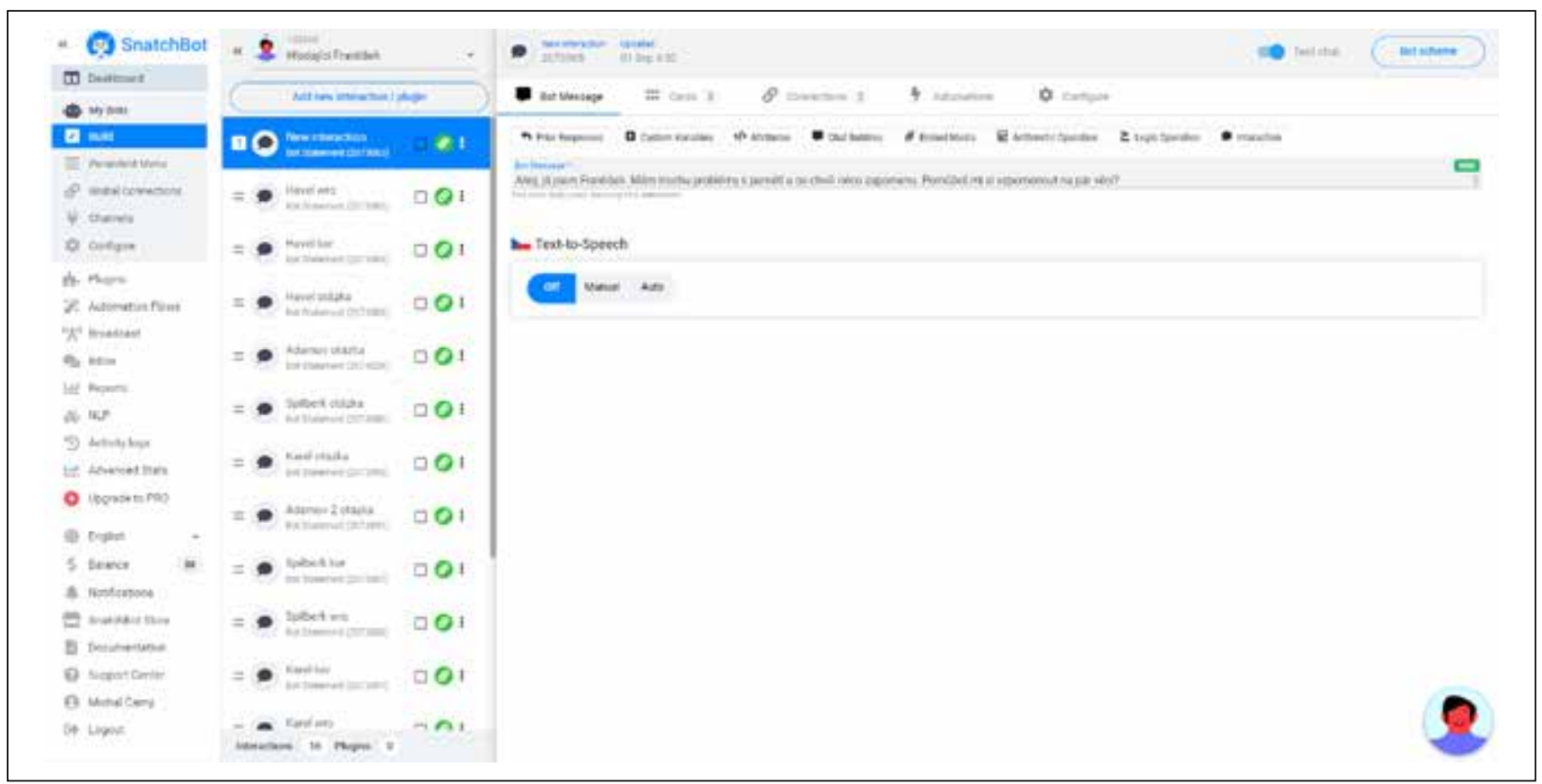

Obr. 1 Snatchbot a jeho základní rozhraní pro tvorbu chatbota

bízí bezplatnou verzi, která nám plně dostačuje. Prostředí je relativně jednoduché - uživatel modeluje dialog (jednotlivá zastavení v něm) a definuje přechody mezi těmito záchytnými body, obecně je tak možné o dialogu přemýšlet ve schématu:

IF uživatel něco napíše THEN jdi na položku X ELSE jdi na položku Y.

Jinými slovy - systém se vždy na základě splnění určité podmínky rozhoduje (na základě toho, co mu nastaví autor dialogu), kam se v řečových aktech může posunout. Záchytný bod je vždy dvojicí vypsání nějaké zprávy a načtení vstupu uživatele, na který je možné určitým způsobem reagovat.

Pro naše potřeby je důležité, že Snatchbot.me umožňuje export chatbota ve formátu samostatné webové stránky, nebo ho pomocí jednoduchého JavaScriptu integruje prímo do stránky. V budoucnu uvažujeme také o exportu chatbota na Facebook, což jsme zatím nevyužili. Technicky jde o jednoduchou věc na pár kliknutí.

Pokud jde o základní funkce, které může uživatel využít tak jde o:
- Práce s textovým vstupem, rozpoznání vstupu nebo práce s tlačítky.

- Vložení URL odkazu do zprávy.

- Vložení obrázku či videa do zprávy.

- Práce s logickými podmínkami a matematickými funkcemi v analýze odpovědi.

- Odkazování do jiných částí dialogu.

- Práce s proměnnými (umožňují např́ílad pracovat s ženskými/mužskými koncovkami v dialogu, vyhodnotit počty správných odpovědí atp.)

- $\quad$ Práce s RSS.

Systém toho ale umí mnohem více, napríklad sbírat data o uživatelích, podporu live chatu v určitých situacích dialogu nebo velice pěknou práci s překlady. Odpověd' uživatele může mít dvě základní podoby, pokud tedy pracujeme s textem v češtině - bud' systém pracuje s tlačítky s krátkou odpovědí, na které uživatel jen kliká, nebo Ize hledat v tvořené textové odpovědi uživatele určité prvky (číslo, část odpovědi,...), podle kterých se určí další postup.

Každému chatbotovi Ize nastavit jméno, profilový ob- 
rázek a prípadně upravit CSS, pomocí kterého Ize měnit vizuální styl, takže výsledek může odpovídat vizuální identitě instituce, která ho chce na svých stránkách využít.

Jak prakticky postupovat při tvorbě? Doporučujeme sledovat následující kroky:

1. Pro pochopení základního ovládání se můžete podívat na naše video na https://youtu.be/VUAWZMiLWyw

2. Stanovte si jasný cíl, co chatbot má studenta naučit nebo k čemu má sloužit.

3. Zkuste si pojmenovat, jak se $k$ tomuto cíli můžete dostat. Ideálně pomocí otázek, které Ize jednoznačně vyhodnocovat.

4. Nakreslete si strukturu na papír - i malý chatbot s pěti otázkami, pokud obsahují zpětnou vazbu pro svoji strukturaci vyžaduje určitou predstavivost.

5. Promyslete si přesně dialogy.

6. Pust'te se do tvorby $v$ aplikaci.

Pokud jde o tvorbu samotnou, tak naše zkušenost je taková, že se velice vyplatí vhodně pojmenovávat všechny dialogové entity tak, at' se k nim Ize vrátit i po několika měsících a chatbot je stále pochopitelný. Velice to usnadní i prvotní návrh chatbota. Pokud je chatbot tvořen jako nějaký testovací systém, navrhněte si napřed linku správných odpovědí, tak aby vše fungovalo a celý průchod byl jednoduchý a funkční. Až $\checkmark$ druhém kroku je možné přidávat cesty pro špatné (nebo alternativní) odpovědi. Vyplatí se přitom postupovat vždy co nejsystematičtěji.
Méně rozsáhlí chatboti se vždy navrhují snáze, než velcí a současně jen málokdy se vyplatí navrhovat skutečně robustní dialogové systémy, protože se $\mathrm{k}$ nim složitě vrací. Náš nejdelší chatbot má jen 26 interakcí, skutečně se velice vyplatí rozložit velká témata na menší, se kterými se snáze pracuje a i student je může projít $v$ nějakém rozumném čase.

\section{VYUŽITÍ V INFORMAČNÍM VZDĚLÁVÁNÍ}

Pokud se podíváme na to, $k$ čemu lze chatboty $v$ informačním vzdělávání využít, domníváme se, že s nimi Ize sledovat tři samostatné cíle. Tím prvním je, že budeme studenty učit chatboty tvořit, což je důležité pro pochopení toho jak fungují a pro rozvoj informatického myšlení. $V$ současné době velkou část informačních interakcích na sociálních sítích realizují právě algoritmické entity, jejichž forma mǔže být s chatbotem často spojená. Jde tedy nejen o rozvoj schopnosti algoritmizovat složitý problém (a především vymyslet funkční dialog), ale také o aktivitu vedoucí k postupnému pochopení toho, jak funguje prostředí, v němž se sami studenti nacházejí. Přesahy využití chatbotů do dalších předmětů jsou zřejmé - Ize pomocí nich konstruovat fiktivní rozhovory s historickými postava$\mathrm{mi}^{12}$, s odborníky na nějaké téma i trénovat slovíčka či počítání príkladů. To vše může být tedy integrováno $v$ tématu chatbotů jako předmětu výuky. Aplikace na tvorbu jsou skutečně tak jednoduché, že by s nimi neměli mít problémy ani žáci osmých tř́́d, takže pro středoškoláky může jít o zajímavé a atraktivní téma.

Druhou oblastí, ve které je možné chatboty využít je informační agenda. Pokud se uživatelé ptají na stále

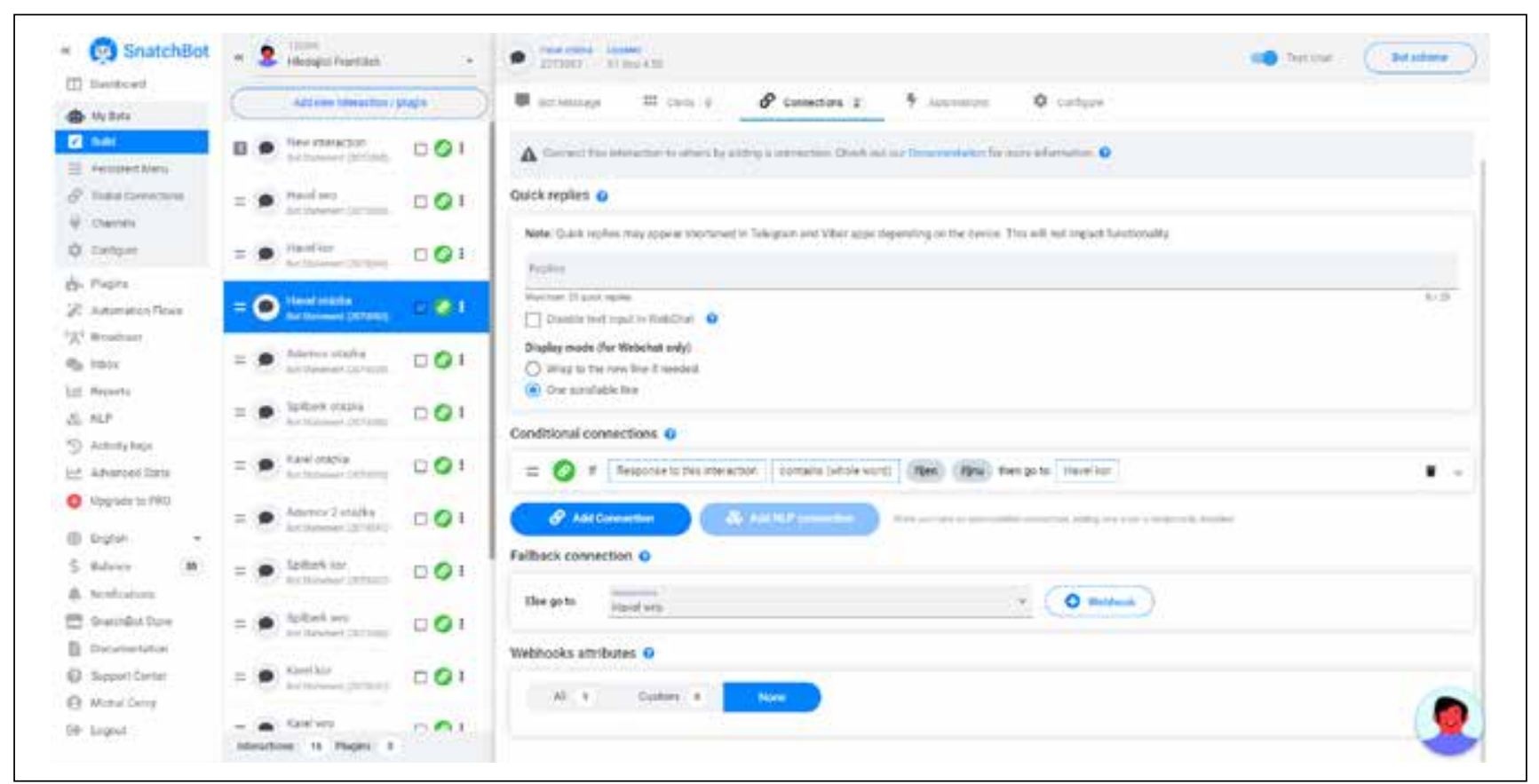

Obr. 2 Ukázka tvorby reakce v dialogu. Pokud odpověd' obsahuje „říjen“ nebo „ríijnu“ jde o správnou odpověd'a dialog postupuje jedním směrem, jinak je odpověd'špatná a student dostává zpětnou vazbu. 
stejné věci, může část otázek a problémů snadno obsloužit chatbot. ${ }^{13}$ Jde tedy o snížení administrativní zátěže a možnost se následně více věnovat rozvoji informační gramotnosti. Právě usnadnění administrativy je $v$ literatuře reflektované téma, byt se domníváme, že v českých a slovenských podmínkách zatím spíše okrajové.

Třetí možností, které se budeme věnovat podrobněji, je využití chatbotů jako nástrojů pro výuku informační gramotnosti. $V$ současné době neexistují žádné komplexní metodiky, které by dávali návody na to, jak $v$ tvorbě chatbotů postupovat. Pokusíme se proto nabídnout tři príklady námi vytvořených chatbotů a z nich poté formulovat doporučení, jako určité zobecnění naší praxe.

\section{PŘÍKLADY}

Vyhledávání informací: $V$ tomto prípadě používáme príklad s Hledajícím Františkem, který dialog se studentem začíná následujícím způsobem: „Ahoj, já jsem František. Mám trochu problémy s pamětí a co chvili něco zapomenu. Pomůžeš mi vzpomenout si na pár věcí?" Snažíme se pracovat s predstavením chatbota a s určitou narativností celé aplikace tak, aby studenty více zaujala a motivovala ve cvičeních pokračovat. Chatbot se studenta bude ptát na pět otázek, které nejsou pamětné, ale vyžadují, aby je student dokázal dohledat, a to za použití různých vyhledávacích nástrojů. Chatbot zde funguje jako doplněk a praktická pomůcka pro procvičení toho, jak dokáží studenti

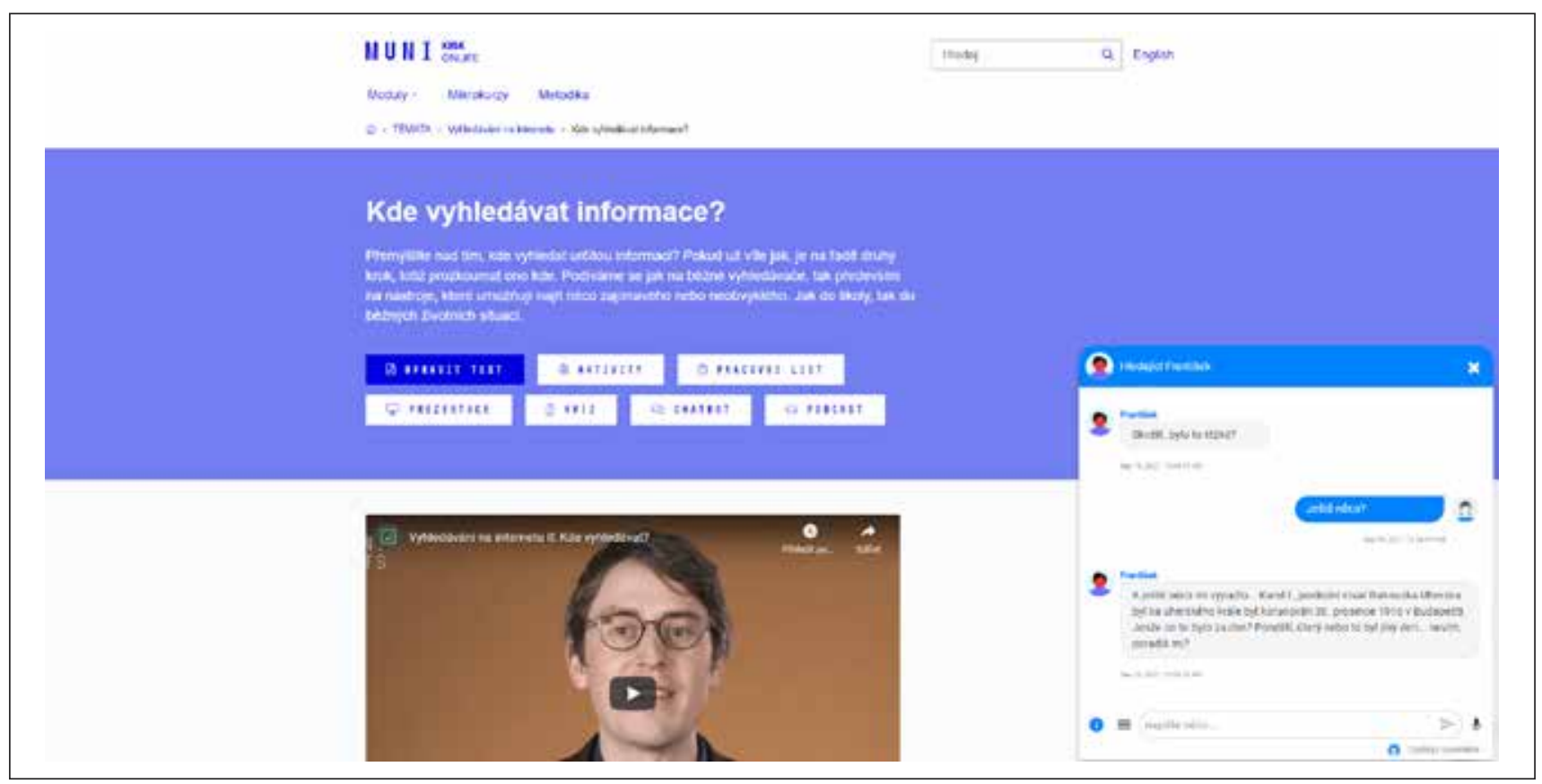

Obr. 3 Ukázka dialogu s Hledajícím Františkem a práce s pozitivní zpětnou vazbou

zpracovat studijní text a prakticky ho použít. Pracujeme s otázkami jako: „A ještě něco mi vypadlo... Karel I., poslední císař Rakouska-Uherska byl na uherského krále korunován 30. prosince 1916 v Budapešti. Jenže co to bylo za den? Pondělí, úterý nebo to byl jiný den... nevím, poradís mi?" - zde pravděpodobně student bude muset vyžít WolphramAlpha nebo „Dlouho premýšlím nad jednou věci... mám výhled z okna na takový hrad... Špilberk, prý vězení národů se mu ř́kalo, ale to se zase zapovídávám. Nevíš komu to dneska patrí? (Prosím přesně!)", což je otázka na práci s katastrem nemovitostí.

Cílem chatbota je tedy podpořit kompetenční učení. Student musí využít různé nástroje, aby se dostal ke správné odpovědi a pokud to nedokáže a odpoví špatně, dostane od chatbota zpětnou vazbu, která ho upozorní, jak by měl prríště postupovat. Obecně pracujeme s postupem, že nenutíme studenta napsat správnou odpověd', bez které nelze jít dál, ale spíše ho upozorňuje na způsob, jak se k odpovědi dostat.

Veronika Zvědavá a diskuse o desinformačním textu Hodnocení informací realizuje chatbot se jménem Veronika Zvědavá. Celkem sedm otázek sleduje techniku hodnocení mediálních sdělení pomocí $5 \mathrm{~W}+\mathrm{H}$ otázek. Úvod je následující: „Ahoj, já jsem Veronika Zvědavá, ráda se věnuji věcem kolem sebe... Ráda bych se Tě zeptala, co si myslís o jedné takové věci... je to opravdu divné, ale četla jsem ted' takový zvláštní článek... Je to tento: > Sudet'áci měli sraz: Zpochybňování výsledků války za podpory našich politiků? Na co všechno nesmíme Zpochybňování výsledků války za podpory na- 


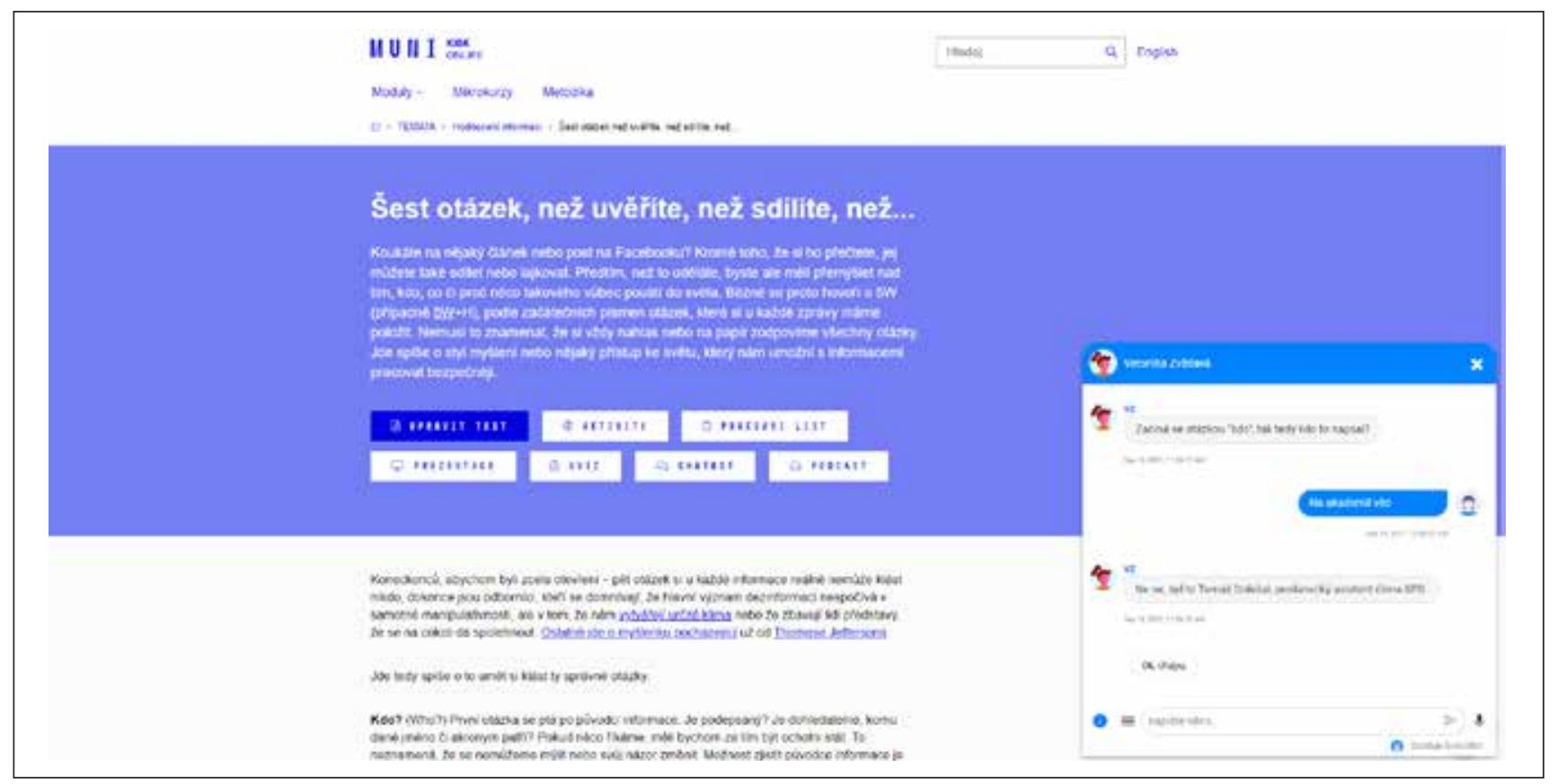

Obr. 4 Veronika Zvědavá a diskuse o desinformačním textu

šich politiků? Na co všechno nesmíme zapomenout. Co by na to řekli tehdejši hrdinové? Bude príšti sjezd u nás? Nikdy, Herr Herman und Herr Posselt! $<<$ Mám $z$ toho divný pocit, pomůžeš mi ho pochopit?"

Celý dialog pracuje s tímto článkem a postupně vede studenta $\mathrm{k}$ tomu, aby si ho otevřel, našel autora, identifikoval vydavatele, jazyk a další charakteristicky textu, které jsou pro hodnocení informací podstatné. Chatbot nabízí bud' faktografické otázky (napište, jak se jmenuje autor článku) nebo „klikací“, tam kde je možné volit jen z několika autorem daných možnosti. Téma hodnocení informací má smysl jen tehdy, když si ho studenti hned prakticky vyzkouší na textu, který se reálně vyskytuje na internetu.

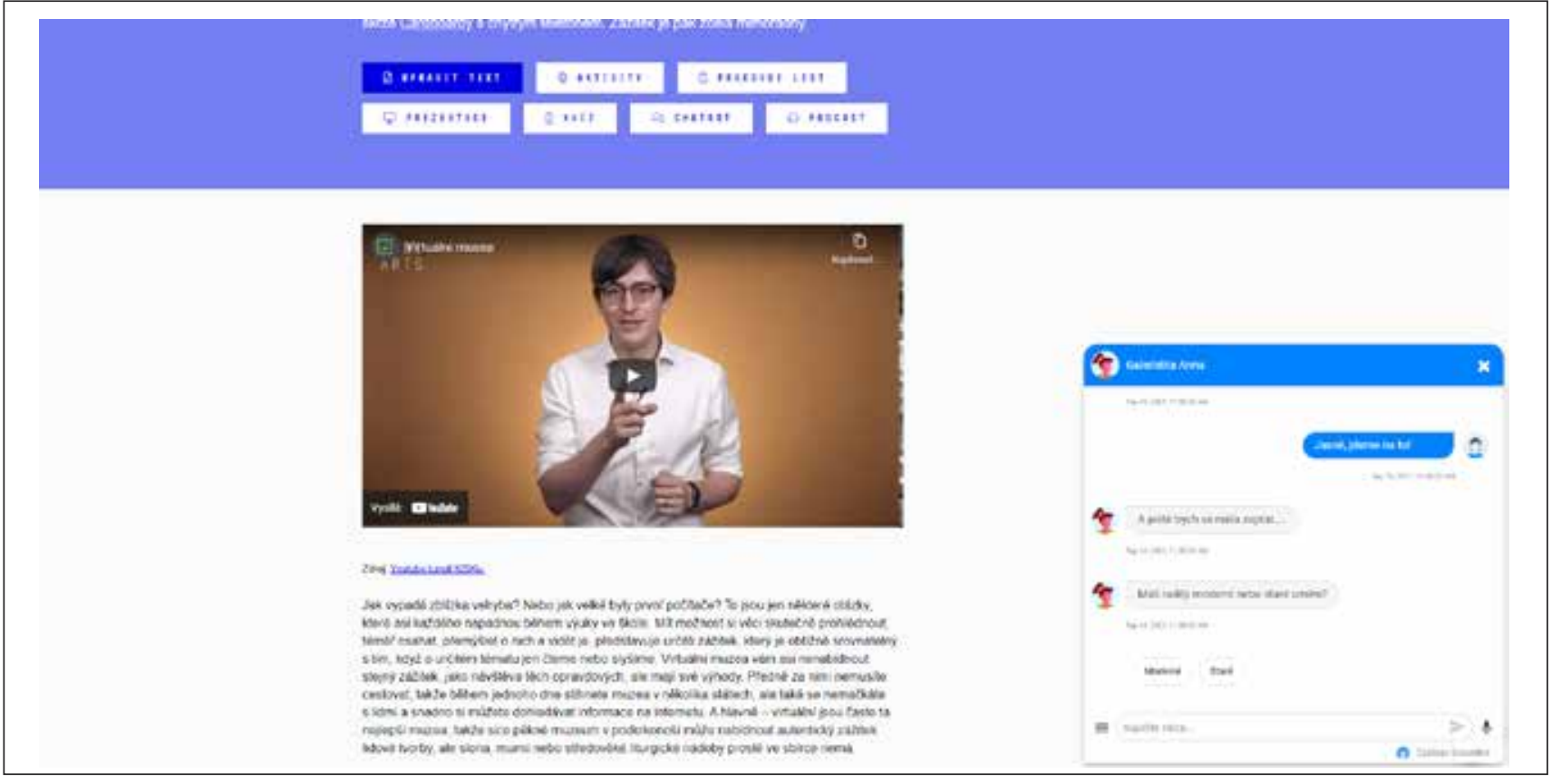

Obr. 5 Ukázka rozhodování u Galeristky Anny, jakým směrem se bude dialog dále ubírat 
Online pamětové instituce procvičuje chatbot - Galeristka Anna. Úvod je podobný, jako u předchozích případů: „Ahoj, já jsem Anna a pracuji v galerii. $V$ poslední době se ale ztratili nějaké obrazy a potřebovala bych si dát dohromady důležité informace, než budu volat pojištovně. Pomůžeš mi prosím?" Student následně zvolí, zda preferuje moderní nebo klasické umění a následuje zápletka spočívající v tom, že z galerie se ztratil obraz konkrétního autora a student musí pomoci Anně s jeho popisem: „Dobře... ztratilo se mi něco od Josefa Čapka... myslím, že je na obraze nějaký člověk, co je celý šedý... jen v rukou drži tahací harmoniku s modrou a červenou barvou... nemáš tušení, co by to mohlo být za dílo?"Opět tedy pracujeme se schopností vyhledávat informace, tentokráte o výtvarných dílech.

Specifikem je, že sledujeme jedno dílo a vedeme studenta, aby nejen našel nějaké základní informace, ale o virtuálních galeriích začal přemýšlet jako o prostoru určité kulturní interakce. Takže se ptáme na otázky jako „To dílo bylo podepsané na divném místě a divným zpưsobem. Vís, jak se tam Čapek podepsal?" nebo „A hrome, ted'mi to došlo... že to dílo nebylo naše, ale máme ho zapưjčené. Prosím Tě, nevišs, kde jsme ho vzali, komu patř́?" Student je tedy vtažen do príběhu, ve kterém Anně pomáhá a současně vyhledává informace a pracuje $s$ uměleckým dílem, což je praktický cíl celého vzdělávacího modulu. Stejně jako $v$ predchozích prípadech, i zde pracujeme se zpětnou vazbou, takže pokud student odpoví špatně, dostane nápovědu, kde by se $\mathrm{k}$ dobré informaci mohl dostat. Chatbot je vlastně obsahově dvojnásobný, protože umožňuje pracovat $s$ moderním i klasickým uměním, což akcentuje určitou personalizaci obsahu, kdy student může získat pocit, že na jeho estetické preferenci v procesu edukace záleží. Opět zde vycházíme ze studií, které akcentují význam konstruktivistického učení založeného na řešení konkrétních problémů, se kterými studenti pracují. $^{14}$

\section{DOPORUČENÍ K OBSAHOVÉ ROVINĚ}

Z výše uvedených príkladů (ale i z dalších, autor textu má v kurzu informační gramotnosti pro středoškoláky sedm chatbotů) vyplývají určitá obecná doporučení, se kterými je možné pracovat. Předně - pro tvorbu chatbota je mnohem důležitější schopnost přemýšlet o dialogu a o tom, co chceme naučit, než programátorská dovednost.

Jako klíčová se jeví snaha pracovat s dialogem - tedy pracovat $s$ príkladem nebo situací a reagovat na to, co student odpovídá. Není možné ho nechat odpovědět špatně nebo správně, neposkytnout mu žádnou zpětnou vazbu. Chatbot je oproti klasickém studijnímu materiálu zajímavý právě tím, že může poskytnout zpětnou vazbu v dialogu. ${ }^{15} \mathrm{~S}$ tímto rozměrem je pak důležité pracovat. Současně platí, že dialog musí být krátký a svižný. Zcela zásadní je schopnost promyslet vzdělávací obsah - co je to, co potřebuje natrénovat, vyzkoušet, procvičit. A pak najít cesty, jak s tím pracovat v dialogu. Chatbot je konstruktivisticky nesmírně zajímavý nástroj, ale může sloužit i pro pamětné nebo faktografické učení v závislosti na tom, kdo s ním pracuje. $V$ prípadě informačního vzdělávání ale konstruktivistický prístup určitě doporučujeme. ${ }^{16}$

Chatbot nemůže nahradit člověka, ale může vést $k$ tomu, že si konkrétní dovednost dokáže jednotlivec rozvinout sám. To nás pak může vést $k$ redesignu a novému promýšlení toho, jak s informačním vzděláváním vůbec pracujeme, protože část vzdělávání můžeme realizovat díky chatbotům a jiné oblasti si ponechat $v$ rovině kontaktní výuky.

Současný diskurs tvorby online vzdělávacích materiálů (viz např́klad FAO manuál) ${ }^{17}$ akcentuje význam profesionalizace; texty, které jsou vysázené ve Wordu nebo grafické úpravy od negrafiků, videa nahraná v kancelárích, to vše postupně ustupuje do pozadí. $K$ tvorbě chatbota, který bude esteticky kvalitní a profesionální ale nic speciálního nepotřebujeme. Stačí jen dobrý profilový obrázek, který bude $v$ souladu $s$ vizuální identitou instituce. $V$ tomto ohledu jde o vzdělávací objekty budoucnosti.

Otázkou je, jak pracovat napríklad s reflektivními úkoly, které miŕí do metakognitivní složky vzdělávání. ${ }^{18}$ Takové pokusy existují, napríklad v našem kurzu jde o Rovnováhu hledajícího Toma, který se ptá studentů, dává jim úkoly $\mathrm{k}$ práci a přemýšlení, ale zpětnou vazbu je schopen poskytovat jen velice omezeně.

Ve všech případech v našem článku pracujeme $s$ tím, že jde o nástroj sebevzdělávací, ${ }^{19}$ nechceme studenta hodnotit, známkovat, nedáváme mu body. Zde respektuje prirozený dialog, skutečnost, že se student sám rozhodl něco se naučit, dozvědět, rozvinout se.

\section{ZÁVĚR}

Zatímco tvorba e-learningových kurzů či tištěných materiálů se stala běžnou součástí informačního vzdělávání a nikoho jejich používání nepřekvapí, chatboti stále představují zajímavou edukační formu, se kterou v informačním vzdělávání př́liš nepracujeme. Chatbot může být na webových stránkách knihovny poskytující informační vzdělávání, ale také součástí presenční lekce, kdy část času stráví studenti na mobilních telefonech či tabletech komunikací s chatbotem.

Samotná tvorba není náročná a tím, že diskurs informační gramotnosti je silně konstruktivistický, vnímáme je jako nástroj pro zlepšení celého procesu edukace $v$ této oblasti. Domníváme se, že neexistuje téma v informační gramotnosti, ke kterému by se nedal vytvoriit chatbot, který by smysluplně aktivizoval studenty. Věŕíme, že jde o jednu z oborově didaktických forem s velkým potenciálem do budoucnosti.

Příspěvek vznik $v$ rámci řešení projektu Platforma pro transfer znalostí: informační gramotnost pro středoškoláky v otevřeném mash-up virtuálním učebním prostředí (TL02000040) podpořeného TAČR. 


\section{Poznámky:}

1. MAZÁČOVÁ, Pavlína, et al. Rozvíjení informační gramotnosti $\checkmark$ edukační praxi $v$ laboratorní základní škole: př́ipadová studie. Gramotnost, pregramotnost a vzdělávání, 2018, 2.2: 21-43.

2. LEVY, Philippa; ROBERTS, Sue (ed.). Developing the new learning environment: the changing role of the academic librarian. Facet Publishing, 2005. či ELDREDGE, Jonathan D. The librarian as tutor/ facilitator in a problem-based learning (PBL) curriculum. Reference services review, 2004.

3. MAZÁČOVÁ, Pavlína. S projektem Co nebylo v učebnici vstř́ic informační gramotnosti žáků. In Bulletin SKIP. Praha: Svaz knihovníků a informačních pracovníků České republiky, 2020. ISSN 1213-5828.

4. LANDOVÁ, Hana; CIVÍNOVÁ, Zdeňka. Aktivity vysokoškolských knihoven v oblasti informačního vzdělávání: vývoj v letech 2006 2010 na veřejných vysokých školách v ČR. Prolnflow, 2010, 2.2.

5. ČERNÝ, Michal. Pojetí informační gramotnosti v ŠVP: analýza kurikula tří vybraných středních škol. Journal of Technology and Information Education. Olomouc: Univerzita Palackého, 2019, roč. 11, č. 2, s. 95108. ISSN 1803-537X. doi:10.5507/jtie.2019.010. ČERNÝ, Michal. Discursive formed topics in information literacy: literature review and high school students' perspectives. Problems of Education in the 21st Century, 2021. roč. 4, č. 79., s. 516-543. 10.33225/pec/21.79.516

6. PASHKOVA-BALKENHOL, Tatiana, et al. Should we flip the script?: A literature review of deficit-based perspectives on first-year undergraduate students' information literacy. Journal of Information Literacy, 2019, 13.2. a ANDREWS, Carl R.; SAINT HILAIRE, Dickens. Aligning the Curriculums for College Success: High School and College Library Collaborations. Community \& Junior College Libraries, 2017, 23.1-2: 41-62.

7. DZULA, Mark, et al. Digital participation and risk contexts in journalism education. Media and Communication, 2020, 8.2: 219231. a JOHNSON, Heather A.; BARRETT, Laura. Your teaching strategy matters: how engagement impacts application in health information literacy instruction. Journal of the Medical Library Association: JMLA, 2017, 105.1: 44.

8. OYEDIRAN-TIDINGS, Stella O.; ONDARI-OKEMWA, Ezra M.; NEKHWEVHA, Fhulu H. Information needs and constraints of access to educational information in the Fort Beaufort Education District. South African Journal of Education, 2019, 39.Supplement 2: S1-S10.

9. GEORGESCU, Alin-Andrei, et al. Chatbots for education - trends, benefits and challenges. In: Conference proceedings of» eLearning and Software for Education "(eLSE). " Carol I" National Defence University Publishing House, 2018. p. 195-200. a MOLNÁR, György; SZÜTS, Zoltán. The role of chatbots in formal education. In: 2018 IEEE 16th International Symposium on Intelligent Systems and Informatics (SISY). IEEE, 2018. p. 000197-000202.

10. PÉREZ, José Quiroga; DARADOUMIS, Thanasis; PUIG, Joan Manuel Marquès. Rediscovering the use of chatbots in education: A systematic literature review. Computer Applications in Engineering Education, 2020, 28.6: 1549-1565. a ROOS, Sofie. Chatbots in education: A passing trend or a valuable pedagogical tool? 2018.

11. Mezi alternativní, podobně orientované nástroje, Ize zařadit např́klad Xenioo, Engati či Chatfuel.

12. HELLER, Bob, et al. Freudbot: An investigation of chatbot technology in distance education. In: EdMedia+ Innovate Learning. Association for the Advancement of Computing in Education (AACE), 2005. p. 39133918. či HELLER, Bob. Conversational Agents as Historical Figures: Persona Effects in the Absence of Visual Information. In: EdMedia+ Innovate Learning. Association for the Advancement of Computing in Education (AACE), 2016. p. 287-291.

13. MOLNÁR, György; SZÜTS, Zoltán. The role of chatbots in formal education. In: 2018 IEEE 16th International Symposium on Intelligent Systems and Informatics (SISY). IEEE, 2018. p. 000197-000202.

14. JOHNSON, Heather A.; BARRETT, Laura. Your teaching strategy matters: how engagement impacts application in health information literacy instruction. Journal of the Medical Library Association: JMLA, 2017, 105.1: 44., LLOYD, Annemaree. Understanding information literacy in the workplace: using a constructivist grounded. Exploring methods in information literacy research, 2007, 67. či NGO, Huyen Thi; PICKARD, Alison Jane; WALTON, Geoff. Information literacy capabilities of upper secondary students: the case of Vietnam. Global Knowledge, Memory and Communication, 2019.

15. CARLESS, David. Feedback as dialogue. Encyclopedia of educational philosophy and theory, 2016, 1-6. a AJJAWI, Rola; BOUD, David. Examining the nature and effects of feedback dialogue. Assessment \& Evaluation in Higher Education, 2018, 43.7: 1106-1119.

16. ALLEN, Maryellen. Promoting critical thinking skills in online information literacy instruction using a constructivistapproach. College \& Undergraduate Libraries, 2008, 15.1-2: 21-38., JOHNSON, Wendell $\mathrm{G}$. The application of learning theory to information literacy. College \& Undergraduate Libraries, 2008, 14.4: 103-120. či MCBRIDE, Mark F. Reconsidering information literacy in the 21st century: The redesign of an information literacy class. Journal of Educational Technology Systems, 2012, 40.3: 287-300.

17. OYE, N. D.;SALLEH, Mazleena; IAHAD, N. A. E-learning methodologies and tools. International Journal of Advanced Computer Science and Applications, 2012, 3.2., VAGARINHO, João Paulo; LLAMASNISTAL, Martin. Process-Oriented Quality in e-Learning: A Proposal for a Global Model. IEEE Access, 2020, 8: 13710-13734. a FAO. 2021. E-learning methodologies and good practices: A guide for designing and delivering e-learning solutions from the FAO elearning Academy, second edition. Rome.

18. CROMLEY, Jennifer G.; KUNZE, Andrea J. Metacognition in education: Translational research. Translational Issues in Psychological Science, 2020, 6.1: 15. či MACCANN-ALFARO, Nancy; GARCÍA-VALCÁRCEL, Ana; MORALES-MORGA, Erla Mariela. Use of ICT to promote and analyze argumentative and metacognitive processes in higher education. In: Proceedings of the Seventh International Conference on Technological Ecosystems for Enhancing Multiculturality. 2019. p. $1028-1034$

19. PETERS-BURTON, Erin E.; BOTOV, Ivan S. Self-regulated learning microanalysis as a tool to inform professional development delivery in real-time. Metacognition and Learning, 2017, 12.1: 45-78. či GARCIA, Rita; FALKNER, Katrina; VIVIAN, Rebecca. Systematic literature review: Self-Regulated Learning strategies using e-learning tools for Computer Science. Computers \& Education, 2018, 123: 150-163. a DE SMUL, Mona, et al. How competent do teachers feel instructing self-regulated learning strategies? Development and validation of the teacher self-efficacy scale to implement self-regulated learning. Teaching and Teacher Education, 2018, 71: 214-225. 


\section{Reference}

AJJAWI, Rola; BOUD, David. Examining the nature and effects of feedback dialogue. Assessment \& Evaluation in Higher Education, 2018, 43.7: 1106-1119.

ALLEN, Maryellen. Promoting critical thinking skills in online information literacy instruction using a constructivist approach. College \& Undergraduate Libraries, 2008, 15.1-2: 21-38.

ANDREWS, Carl R.; SAINT HILAIRE, Dickens. Aligning the Curriculums for College Success: High School and College Library Collaborations. Community \& Junior College Libraries, 2017, 23.1-2: 4162.

CARLESS, David. Feedback as dialogue. Encyclopedia of educational philosophy and theory, 2016, 1-6.

ČERNÝ, Michal. Discursive formed topics in information literacy: literature review and high school students' perspectives. Problems of Education in the 21st Century, 2021. roč. 4, č. 79., s. 516-543. 10.33225/pec/21.79.516 ČERNÝ, Michal. Pojetí informační gramotnosti v ŠVP: analýza kurikula trí vybraných středních škol. Journal of Technology and Information Education. Olomouc: Univerzita Palackého, 2019, roč. 11, č. 2, s. 95-108, 14 s. ISSN 1803-537X. doi:10.5507/jtie.2019.010.

DE SMUL, Mona, et al. How competent do teachers feel instructing self-regulated learning strategies? Development and validation of the teacher self-efficacy scale to implement self-regulated learning. Teaching and Teacher Education, 2018, 71: 214-225.

DZULA, Mark, et al. Digital participation and risk contexts in journalism education. Media and Communication, 2020, 8.2: 219-231.

ELDREDGE, Jonathan D. The librarian as tutor/facilitator in a problembased learning (PBL) curriculum. Reference services review, 2004.

FAO. 2021. E-learning methodologies and good practices: A guide for designing and delivering e-learning solutions from the FAO elearning Academy, second edition. Rome. CROMLEY, Jennifer G.; KUNZE, Andrea J. Metacognition in education: Translational research. Translational Issues in Psychological Science, 2020, 6.1: 15.

GARCIA, Rita; FALKNER, Katrina; VIVIAN, Rebecca. Systematic literature review: Self-Regulated Learning strategies using e-learning tools for Computer Science. Computers \& Education, 2018, 123: 150-163.

GEORGESCU, Alin-Andrei, et al. Chatbots for education-trends, benefits and challenges. In: Conference proceedings of» eLearning and Software for Education «(eLSE). " Carol I" National Defence University Publishing House, 2018. p. 195-200.

HELLER, Bob, et al. Freudbot: An investigation of chatbot technology in distance education. In: EdMedia+ Innovate Learning. Association for the Advancement of Computing in Education (AACE), 2005. p. 3913-3918.

HELLER, Bob. Conversational Agents as Historical Figures: Persona Effects in the Absence of Visual Information. In: EdMedia+ Innovate Learning. Association for the Advancement of Computing in Education (AACE), 2016. p. 287-291.

JOHNSON, Heather A.; BARRETT, Laura. Your teaching strategy matters: how engagement impacts application in health information literacy instruction. Journal of the Medical Library Association: JMLA, 2017, 105.1: 44 .

JOHNSON, Heather A.; BARRETT, Laura. Your teaching strategy matters: how engagement impacts application in health information literacy instruction. Journal of the Medical Library Association: JMLA, 2017,
105.1: 44.

JOHNSON, Wendell G. The application of learning theory to information literacy. College \& Undergraduate Libraries, 2008, 14.4: 103-120.

LANDOVÁ, Hana; CIVÍNOVÁ, Zdeňka. Aktivity vysokoškolských knihoven v oblasti informačního vzdělávání: vývoj v letech 2006 - 2010 na veřejných vysokých školách v ČR. Prolnflow, 2010, 2.2.

LEVY, Philippa; ROBERTS, Sue (ed.). Developing the new learning environment: the changing role of the academic librarian. Facet Publishing, 2005.

LLOYD, Annemaree. Understanding information literacy in the workplace: using a constructivist grounded. Exploring methods in information literacy research, 2007, 67.

MACCANN-ALFARO, Nancy; GARCÍA-VALCÁRCEL, Ana; MORALESMORGA, Erla Mariela. Use of ICT to promote and analyze argumentative and metacognitive processes in higher education. In: Proceedings of the Seventh International Conference on Technological Ecosystems for Enhancing Multiculturality. 2019. p. 1028-1034.

MAZÁČOVÁ, Pavlína, et al. Rozvijení informační gramotnosti v edukační praxi $v$ laboratorní základní škole: prípadová studie. Gramotnost, pregramotnost a vzdělávání, 2018, 2.2: 21-43.

MAZÁČOVÁ, Pavlína. S projektem Co nebylo v učebnici vstříc informační gramotnosti žáků. In Bulletin SKIP. Praha: Svaz knihovníků a informačních pracovníků České republiky, 2020. ISSN 1213-5828.

MCBRIDE, Mark F. Reconsidering information literacy in the 21st century: The redesign of an information literacy class. Journal of Educational Technology Systems, 2012, 40.3: 287-300.

MOLNÁR, György; SZÜTS, Zoltán. The role of chatbots in formal education. In: 2018 IEEE 16th International Symposium on Intelligent Systems and Informatics (SISY). IEEE, 2018. p. 000197-000202.

NGO, Huyen Thi; PICKARD, Alison Jane; WALTON, Geoff. Information literacy capabilities of upper secondary students: the case of Vietnam. Global Knowledge, Memory and Communication, 2019.

OYE, N. D.; SALLEH, Mazleena; IAHAD, N. A. E-learning methodologies and tools. International Journal of Advanced Computer Science and Applications, 2012, 3.2.,

OYEDIRAN-TIDINGS, Stella O.; ONDARI-OKEMWA, EZra M.; NEKHWEVHA, Fhulu $\mathrm{H}$. Information needs and constraints of access to educational information in the Fort Beaufort Education District. South African Journal of Education, 2019, 39.Supplement 2: S1-S10.

PASHKOVA-BALKENHOL, Tatiana, et al. Should we flip the script?: A literature review of deficit-based perspectives on first-year undergraduate students' information literacy. Journal of Information Literacy, 2019, 13.2.

PÉREZ, José Quiroga; DARADOUMIS, Thanasis; PUIG, Joan Manuel Marquès. Rediscovering the use of chatbots in education: A systematic literature review. Computer Applications in Engineering Education, 2020, 28.6: 1549-1565.

PETERS-BURTON, Erin E.; BOTOV, Ivan S. Self-regulated learning microanalysis as a tool to inform professional development delivery in real-time. Metacognition and Learning, 2017, 12.1: 45-78.

ROOS, Sofie. Chatbots in education: A passing trend or a valuable pedagogical tool? 2018.

VAGARINHO, João Paulo; LLAMAS-NISTAL, Martin. Process-Oriented Quality in e-Learning: A Proposal for a Global Model. IEEE Access, 2020, 8: $13710-13734$. 